\title{
Development of a Uniform Insolvency Law in SADC: Lessons from OHADA
}

\author{
Ngaundje Doris Leno*
}

\begin{abstract}
This article argues that, with the global or cross-border nature of many corporate activities, there is an increasing need for a uniform insolvency law approach to the financial distress of a corporation in the Southern African Development Community. In doing so, the article highlights lessons the community may learn from the Insolvency Act of the Organisation for the Harmonization of Business Law in Africa. Emphasis is given to that organization's success in developing a uniform insolvency act (ie one which is directly applicable in its contracting states). The article also proposes a number of recommendations.
\end{abstract}

\section{INTRODUCTION}

Globalization has caused the world of business to appear smaller each day, not in size but in the ease with which goods and services are accessible to the rest of the world. This is an advance of globalization in the 21st century. It is evident that no country can depend solely on its national law, isolate itself from its neighbours or avoid having contact with other nations. ${ }^{1}$ Since insolvency is often an inevitable aspect of business activity, it is necessary for states to develop a uniform insolvency law approach (UILA) to regulate cross-border insolvency disputes. This need was clearly stated by Molengraff when he wrote:

"The increasing international intercourse, the increasing community of interests has gradually led to the realization that [sic] human race does not consist of a collection of as many separate and individual societies of legal communities as there are states, but it constitutes one society, one legal community notwithstanding the fact that legislation and administration of justice are locally different and that the world has been divided into states, just as each has been divided into provinces and districts, for the purpose of orderly administration. The society of mankind constitutes one body that has commissioned the care of certain interests to a number of governments, each

* LLD candidate, University of Pretoria, South Africa. This article, written under the supervision and support of Professor Andre Boraine, is based on a paper delivered on 10 June 2010 at the academic meeting of the 2010 conference of INSOL International held in Dublin, Ireland.

1 See G Bertucci and A Alberti "Globalization and the role of the state: Challenges and perspectives”, available at: <http://unpan1.un.org/intradoc/groups/public/documents/ un/unpan006225.pdf> (last accessed 29 April 2013). 
operating within an assigned territory. This consciousness is continuously growing and expressing itself in various ways in the field of the law. It is on account of this growing consciousness of the unity of the human race that a world law is coming into being, also in the field of [insolvency law]."

Globalization focuses the usefulness of a UILA whose primary aim is the resolution of cross-border insolvency disputes. The underlying objective of a UILA would be to create a level playing field, to avoid a race to the bottom and forum shopping practices. ${ }^{3}$ Enacting provisions with these objectives would remove present uncertainty regarding the scope of existing national legislative provisions and restore investors' confidence. ${ }^{4}$ The Organisation for the Harmonization of Business Law in Africa (OHADA) and the Southern African Development Community (SADC) are both international organizations created to attain goals shared by their member states. ${ }^{5}$ However, the visions of OHADA and SADC are different. In accordance with article 1 of the OHADA Treaty, ${ }^{6}$ OHADA aims at the unification of substantive commercial laws of its member states. To this effect, it has adopted nine uniform acts, ${ }^{7}$ one of which is the Insolvency Act (OIA). ${ }^{8}$ By implication, there is no difficulty in arriving at the proper law or even jurisdiction in the event of a cross-border insolvency dispute within the region. On the other hand, SADC does not operate a uniform commercial law system and as such no attempt has been made to unify the commercial laws or private international rules applicable to cross-border disputes. ${ }^{9}$ This invariably means that, in the event of a cross-border insolvency dispute, the debtor will be subject to diverse national insolvency law regimes.

This diverse approach is wasteful and will engender increased transaction costs, and uncertainty as to the applicable law and jurisdiction, which in turn may drive away investors. It also raises "considerable problems for policy

2 Cited in Y Ademola Harmonisation of Laws in Africa (1999, Malthouse Press Ltd) at 44.

3 Pauwelyn defined forum shopping as "a litigant's attempt to have his action tried in a particular court or jurisdiction where he feels he will receive the most favourable treatment or verdict”; see J Pauwelyn "Going global, regional, or both? Dispute settlement in the Southern African Development Community (SADC) and overlaps with the WTO and other jurisdictions" (2004) 13 Minnesota Journal of Global Trade, Inc 231 at 234. With regard to insolvency, it is situation where a debtor decides to transfer assets or proceedings from one member state to another in order to secure a more favourable legal position: recital 4 of the EU Insolvency Regulation of 2000.

4 B Wessel (ed) Cross-Border Insolvency: International Instruments and Commentary (2007, Kluwer Law International) at 9.

5 International organizations may be described as a platform for interaction between and among various states; see JHH Weiller The Constitution of Europe: Do the New Clothes Have an Emperor? And Other Essays on European Integration (1999, Cambridge University Press) at 273.

617 October 1993, as amended by the Revised OHADA Treaty, 17 October 2008. The Revised Treaty came into force on 21 March 2010.

7 Id, art 2.

81 January 1999.

9 SADC Treaty, art 5. 
and programme coordination and harmonisation". ${ }^{10}$ With regard to this shortfall and the large volume of cross-border transactions enabled by free movement of goods and services, persons and capital, SADC needs to embark on a comprehensive review and reform of its laws. ${ }^{11}$ This will make it easier to identify the applicable law, minimize fraud committed by debtors, expedite the determination of cases, and save time and resources in the resolution of disputes. The moot point, however, is whether there is the need for a UILA in SADC. This article argues that there is, as a considerable number of factors support this view.

Luckily, SADC can learn from the benefits of the OIA. ${ }^{12}$ This argument is strengthened by OHADA's success in developing a uniform insolvency act (that is one which is directly applicable in its contracting states). As Mazrui aptly admonished, "Africa must stand ready to selectively borrow, adapt, and creatively formulate its strategies for planned development". ${ }^{13}$ The overriding aim of this article is to highlight the lessons SADC can learn from the OIA in developing its own UILA. Against this backdrop, the author intends to provide an understanding of SADC and to discuss the factors which support a UILA in the region. ${ }^{14}$ This is followed by an understanding of OHADA and the OIA with the view of determining the lessons SADC can learn and concluding with some recommendations for SADC. The current state of affairs in SADC illustrates the need to study the OIA. Studying the OIA would contribute to the corpus of knowledge, as it would provide an understanding of the OIA in SADC; it would also avail SADC member states of the benefits of a UILA.

\section{THE SOUTHERN AFRICAN DEVELOPMENT COMMUNITY}

SADC is a "treaty-based organisation", 15 in the sense that it was established within the framework of an agreement ${ }^{16}$ between those southern African states (Angola, Botswana, the Democratic Republic of Congo, Lesotho, Madagascar, Malawi, Mauritius, Mozambique, Namibia, Seychelles, South

10 DJ Nangela "Harmonisation of national laws in the context of SADC regional integration: Analysis of SADC's initiatives in the area of e- commerce" (paper presented at the first annual SADC law seminar series on SADC law, "Building towards regional integration", University of Cape Town, 17-18 November 2011) at 22.

11 EN Sayi Harmonisation of Insolvency Law in East African Community (LLM dissertation, Vrije University, Amsterdam, 2006) at 23.

12 Above at note 8.

13 See A Mazrui and M Tidy Nationalism and New States in Africa (1985, Heinemann) at 85.

14 L Marts Globalization and the Southern African Countries (2004, Elanders Inforlogistics Vast $\mathrm{AB})$ at 15.

15 PQC Sands and P Klein Bowette's Law of International Institutions (2009, Sweet \& Maxwell) at 16 .

16 The Treaty of SADC, Windhoek, 17 August 1992. After citing the objectives previously enunciated in "Southern African toward economic liberation" (a declaration by the governments of independent states of southern Africa made at Lusaka, 1 April 1980), the treaty established the SADC. 
Africa, Swaziland, Tanzania, Zambia and Zimbabwe) which are in the process of tying their economies together, to some extent, and which co-operate on various policy levels, be it human rights, politics or social. ${ }^{17}$ SADC's main task is to create a development community through regional co-operation and integration for the economic liberation and development of the community. ${ }^{18}$ Towards this end, SADC has created community organs to oversee the implementation of its objectives. ${ }^{19}$

What is striking though is that SADC member states do not have a common legal tradition, language, currency or uniform commercial insolvency law, and there are no proposals to reform commercial laws in the region. ${ }^{20}$ These are all questions which come to mind when an investor or economic operator wants to invest in a region. The diversity within SADC has become even more apparent with the growing intercourse between its member states. ${ }^{21}$ This diversity is compounded by the fact that SADC states are not parties to an international convention or treaty on the harmonization of their commercial laws. The consequences of the diversity heighten the urgency for unified commercial legislation, particularly unified insolvency legislation to deal with cross-border insolvency disputes. The key advantage of having one concursus creditorium [insolvency proceeding] is obvious: it ensures a fair division of the company's property among its creditors according to their legal rights. $^{22}$

\section{The need for a UILA in SADC}

Cross-border insolvency refers to a situation where a debtor has assets and debts or both in a number of jurisdictions. Such situations have grown rapidly following the advent of globalization, which rendered the world a global village. When this arises in SADC, the following questions will arise. First, which country's law is applicable to the control of the assets and debts of the debtor? Secondly, in which country's courts will the dispute be litigated? Thirdly, with what ease will a judgment obtained in one country be enforced in another? ${ }^{23}$ Hitherto, these questions have not been addressed by any

17 T Kruger "Regional organizations and their dispute settlement bodies" 2008 De Jure 306.

18 SADC Treaty, art 21(3)(a), (b), (c), (d), (e), (f) and (g). Art 21 sets the areas of cooperation, ranging from food security and agriculture, to international relations and peace.

19 Id, art 9. See D Leno "Regionalism: Lessons the SADC can learn from OHADA" (2012) 75 Contemporary Roman-Dutch Law 256 at 259.

20 B Chinsinga "The challenges of globalization and regional integration: The case of the Southern African Development Community" in M Milazi (eds) Democracy, Human Rights and Regional Co-operation (2002, Africa Institute of South Africa) 115.

21 See HN Kurt "The national bankruptcy act and the conflict of laws" (1946) 59 Harvard Law Review 1025.

22 D Ailola "Recognition of foreign proceedings, orders and officials in insolvency in southern Africa: A call for a regional convention" (1999) 32 Comparative and International Law Journal of Southern Africa 54 at 57.

23 R Mason "Cross-border insolvency law: Where private international law and insolvency law meet” in Omar J (ed) International Insolvency Law: Themes and Perspectives (2008, 
attempt to unify the private international rules applicable to cross-border disputes. This is not a very good picture for a region whose governments are avowedly committed to alleviating poverty and improving cross-border trade. ${ }^{24}$

Imagine a debtor in South Africa who has assets or debts in Namibia and Botswana, and against whom insolvency proceedings have been instituted in South Africa. The fact that these countries are not parties to an international convention or treaty on cross-border insolvency ${ }^{25}$ means that the assets and debts of the debtor cannot be decided and controlled in South Africa without the assistance of the courts, lawyers and administrative staff of the other states and application of the conflict of law rules of the other states. ${ }^{26}$ On the relevance of conflict of laws, Lord Nicholls of Birkenhead explains that:

\begin{abstract}
"Conflict of laws jurisprudence is concerned essentially with the just disposal of proceedings having a foreign element. The jurisprudence is founded on the recognition that in proceedings having connections with more than one country an issue brought before a court in one country may be more appropriately decided by reference to the laws of another country even though those laws are different from the law of the forum court."27
\end{abstract}

For his part, Prosser describes the realm of conflict of laws as "a dismal swamp, filled with quaking quagmire, and inhabited by learned but eccentric professors who theorized about mysterious matter in a strange and incomprehensible jargon". ${ }^{28}$ For Mason, conflict of laws "ignores the challenges that globalization presents to laws affecting a state's participation in cross-border trade and commerce". ${ }^{29}$ Conflict of laws is an impediment to cross-border commercial activity. ${ }^{30}$ It impairs states and individuals from not only entering into cross-border transactions, but also their participation in such transactions, for fear of the unknown. Similarly, it impedes the achievement of

contd

Ashgate Publishing Co) 27 at 39; see PE Nygh and M Davies Conflict of Laws in Australia (7th ed, 2002, LexisNexis Butterworth) at 6-7.

24 See the preamble of the SADC Treaty as amended in 2001.

25 South Africa in fact adopted a Cross-Border Insolvency Act 42 in 2000, but it is not yet in force because the minister of justice has not yet designated the relevant countries to which it will apply.

26 D McClean and K Beevers The Conflict of Laws (6th ed, 2005, Sweet \& Maxwell) at 2-3.

27 Ibid.

28 See D Prosser "Interstate publication” (1951) 51 Michigan Law Review 959 at 971.

29 See Mason "Cross-border insolvency law", above at note 23 at 41.

30 See $\mathrm{AD}$ Walsh and KW Ryan "Harmonization and standardization of legal aspects of international trade" (1977) 51 Australian Law Journal 608; see also "HL Hayes "A modern lex mercatoria [merchant law]: Political rhetoric or substantive progress?" (1977) 3 Brooklyne Journal International Law 210 and BM Cremades and LS Plehn "The new lex mercatoria and the harmonisation of the laws of international commercial transactions" (1984) 3 Boston Uniform International Law Journal 317. 
the objectives of economic integration schemes and the economic development of southern African states. ${ }^{31}$ It is prodigiously for these reasons that this article invites SADC to end the legal balkanization of the different insolvency laws in all their forms and embrace a UILA to facilitate trade and investment and the resolution of cross-border insolvency disputes in the region. ${ }^{32}$

The need for the recognition of foreign proceedings, orders and officials and the enforcement of foreign judgements in proceedings in SADC can be concluded from the reports of the few cases there have been. ${ }^{33}$ Sackstein NO $v$ Proudfoot SA (Pty) Limited ${ }^{34}$ (Sackstein) demonstrates the consequences of lack of co-operation and the need for an appropriate legal facility to provide for cross-border claims. ${ }^{35}$ The facts of the case were as follows. Tsumeb Corporation Limited, a Namibian company (TCL Namibia), was registered in South Africa as an external company (TCL SA). ${ }^{36}$ The companies were placed under provisional liquidation in Namibia and South Africa respectively. ${ }^{37}$ As a result of a scheme of arrangement entered into under section 311 of the Namibian Companies Act, ${ }^{38}$ TCL Namibia was discharged from liquidation, meaning it was no longer insolvent. Sackstein was appointed liquidator in South Africa. In the absence of a binding insolvency convention between South Africa and Namibia, Sackstein was required to approach the Namibian High Court for recognition, with the aim of impeaching voidable transactions relating to the property of a company situated outside South Africa. However, instead of approaching the Namibian High Court for recognition with the aim of invoking the Namibian avoidance, ${ }^{39}$ Sackstein brought an action against Proudfoot Limited, a South African company, to recover payments made to it by TCL Namibia ${ }^{40}$ on the grounds that TCL Namibia and TCL SA were one and the same entity.

The question that arose was whether Sackstein was entitled to impeach voidable transactions relating to the property of a company situated outside South

31 B Gbenga "Transnational law, unification and harmonisation of international commercial law in Africa” (1994) 38(2) Journal of African Law 125.

32 See "China as a river of regional integration in Africa: Prospects for the future", available at: <http://www.ccs.org.za/downloads/DBSA\%20Conference\%20Report.pdf> (last accessed 16 December 2011).

33 For example, Sackstein NO v Proudfoot SA (Pty) Limited [2003] 4 SCA 348; and Ward v Smith and Others: In Re Gurr v Zambia Airways Corp Ltd [1998] 3 SA 175. See "South Africa" in INSOL International Cross-border Insolvency: A Guide to Recognition and Enforcement (2003, INSOL International), chap 32. Ibid.

35 See D Ailola "Recognition of foreign proceedings", above at note 22.

36 Sec 323 of the Companies Act 61 of 1973, as amended by the Companies Bill of 2008.

37 In Namibia on 29 April 1998 and in South Africa on 29 July 1998.

38 That was on 10 March 2000.

39 A Boraine "Avoidance provisions in a local and cross-border context: A comparative overview" 2008 INSOL International (Technical Series Issue No 7) at 21-22.

40 This was in terms of sec 29(1) of South Africa's Insolvency Act, no 24 of 1936, dealing with voidable dispositions and sec 30 dealing with voidable preferences. 
Africa. Relying on South Africa's Insolvency Act ${ }^{41}$ (SAIA) and the doctrine of territoriality, the Witwatersrand local division held in favour of Proudfoot on the basis that "the South Africa liquidator [Sackstein] had no power to impeach these dispositions" 42 because it was an act of the Namibian company and not that of South Africa and also because a liquidator's powers to impeach could only be exercised in respect of transactions in their respective country. ${ }^{43}$

Within the OHADA context, there would be a different and more desirable outcome because countries are subject to a certain legal regime. However, it is important to note that the OIA applies to joint treatment of insolvency proceedings. Joint insolvency may result from two instances. First, it may result when an enterprise has assets or debts in a number of jurisdictions. Secondly, it may result when a company registered, say, in Cameroon is a subsidiary of a parent company located in, say, Senegal. In both instances, collective or simultaneous proceedings with extra-territorial effect may be commenced against the debtor. It is equally important to note that dispositions made during the "suspect period", ${ }^{4}$ not for value, or where the debtor's obligations far outweigh those of the other party ${ }^{45}$ can be set aside by the court upon the administrator's request. ${ }^{46}$ This is to avoid any preferential treatment of a creditor over other creditors or fraudulent transfer of the debtor's assets. In doing so, the administrator must prove that the disposition was not made for value, in the ordinary course of business or to favour a particular creditor over others (by making payment of pre-existing debts). ${ }^{47}$ Considering that Sackstein occurred within the OHADA region, both companies would be regarded as one and the same entity. Given that only the branch was insolvent, secondary proceedings would be opened in respect of the branch and, if the dispositions of the parent company affected the branch, then the liquidator appointed for the branch would be required under the OIA to collaborate with the appointed administrator of the parent company in setting the disposition aside in accordance with the OIA. The liquidator of the branch would not need to apply for recognition in the court of the country where the administrative proceedings commenced because recognition would be automatic.

Apart from the difficulties encountered in seeking to collect assets in a foreign jurisdiction, the risk local creditors faced in receiving payment from a foreign company registered as an external company is another major

41 Act No 24 of 1936.

42 A Smith and A Boraine "Cross-border insolvency law and the local creditor's risk of receiving payment from a foreign company registered as an external company in South Africa" (2004) 16 South African Mercantile Law Journal 495 at 496.

43 Id at 499.

44 The "suspect period" is the period between the date of insolvency and date of judgment. This is limited to a period of 18 months.

45 OIA, art 69.

46 Id, art 67.

47 Id, art 69(4)(2). 
problem. ${ }^{48}$ Scott JA in the leading case of Ward $v$ Smith and Others: In re Gurr v Zambian Air Ways Corporation Ltd avers that "where there is both local concursus [proceedings] and a foreign concursus, it may well be that one group of creditors will either be favoured or disadvantaged depending on the location of the company's assets". ${ }^{49}$ By implication, creditors in the country in which assets of the debtor are located would be highly favoured. This is evident in South Africa where, under common law rules, local creditors enjoy preference over foreign creditors regarding assets located within the republic. ${ }^{50}$ Accordingly, the words of Forsyth are very important when he said "only those whose whole cause of action arose within the republic or who is an incola of the republic shall ... acquire any right to prove [sic] secured or preference claim". ${ }^{51}$ This was confirmed by Chief Burton $\mathrm{R}$ in the petition of Hourani when he said: "[w]ithout efforts towards coordination between the laws and tribunals of different jurisdiction, a degree of asset waste and turmoil from failed cross-border transactions is virtually certain to result when selfish interested creditors seek to gain advantage for themselves under one's country [sic] system regardless of the impact on other creditors." ${ }^{22}$

While there is nothing wrong with personal initiatives, they cannot be applied without regard to the foreign element. Equally, the question of recognition and enforcement of foreign proceedings, orders and officials remains largely a domestic matter. South African courts, like their counterparts in other SADC states, require the trustee or liquidator of the debtor who wishes to retrieve assets in a foreign state to file with the relevant foreign court a request for recognition ${ }^{53}$ which in the respective countries may be done on the basis of comity and convenience. ${ }^{54}$ In Ex parte Wessels and Venter NNO: In re Pyke-Not'Insolvent Estate, 55 the South African court added a new condition for recognition when it stated that "recognition should only be given where the applicant can make out a prima facie case or has a reasonable prospect of success". ${ }^{56}$ It implies that an official seeking to recover assets must ensure that the case has a reasonable chance of success. In Namibia, the courts can

\footnotetext{
48 Smith and Boraine "Cross-border insolvency law", above note 42 at 498.

49 Above at note 33 at 10.

50 J Franco “The cross-border insolvency act: Lifting the barriers or creating new ones?" (2003) 15 South African Mercantile Law Journal 27 at 31.

51 Ex parte Steyn [1979] 2 SA 309(0) at 312c. This point was criticized by A Smith and A Boraine "The grab rule foils the foreign liquidator in his own jurisdiction" (2002) American Bankruptcy Institute Law Review 135 at 184.

52 Smith and Boraine "Cross-border insolvency law", above note 42 at 496.

53 E Bertelsmann Mars: The Law of Insolvency in South Africa (9th ed, 2008, Juta Law Publishers) at 671.

54 Ex parte Palmer NO: In re Hahn [1993] 3 SA 359(c); Ex parte Stegmann [1902] TS 40; Moolman v Builders and Developers (Pty) Ltd [1990] 1 SA 954 (A) 961C; and Clegg v Priestly [1985] 3 SA 950(w).

55 [1996] 2 SA 681.

56 See Ailola "Recognition of foreign proceedings", above at note 22 at 63.
} 
only confirm a provisional order or judgment and enforce a foreign judgment if it is final. ${ }^{57}$

Another significant reason is to protect employees during insolvency. Corporate insolvency affects parties with interests ${ }^{58}$ and investment in the corporation, but its impact on employees is significant. ${ }^{59}$ This is because of employees' contributions ${ }^{60}$ and the losses they suffer. There is the risk of loss of employment, wage and other compensation claims and pension savings in the case of pensioners. While there is broad acknowledgment of these losses, there is no uniform approach in SADC regarding employee protection. To illustrate this point, upon insolvency in South Africa, employment contracts terminate automatically 45 days after the appointment of the final trustee or liquidator. This is subject to compensation being payable for damages sustained as a consequence of that termination. ${ }^{61}$ The differences between SADC countries in this regard lie in employees' positions on the ladder of payments. In South Africa, employees occupy the fifth position; in Namibia it is the sixth and it is the fourth in Botswana. ${ }^{62}$ It should however be mentioned that these countries recognize the preferential rights of employees but do not provide for compulsory insurance or a guarantee fund to pay salaries and other benefits in arrears at the time of insolvency, as provided in part III of the International Labour Organization Convention on Insolvency. ${ }^{63}$ This indicates that, in the event of bankruptcy, employees are paid from the proceeds of the insolvent estate. In principle, rights of all secured creditors rank in priority to those of employee creditors, meaning secured creditors are paid before employees.

Another significant difference lies in the rights and obligations of employees in respect of the transfer of an undertaking under circumstances of insolvency. In the South African context, once it is ascertained that a business is being transferred in insolvent circumstances, the consequences are that the new employer is automatically bound to all existing contracts of employment and all rights and obligations between the previous employer and each employee, ${ }^{64}$ unless agreed otherwise by the employees and the new employer

57 Bekker NO $v$ Kotze and Another [1996] 4 SA 1287 (Nm); [1996] 4 SA 1293 (Nm).

58 See JP Sarra Creditors Rights and the Public Interest, Restructuring Insolvent Corporations (2003, University of Toronto Press) at 70.

59 JP Sarra "Widening the insolvency lens: The treatment of employees claims" in Omar (ed) International Insolvency Law, above at note 23, 295.

60 Employees contribute to the productivity of a firm in terms of their labour inputs, time, energy and loyalty, which enhances the firm's value.

61 In South Africa, contracts of employment terminate 45 days after the appointment of the final trustee or liquidator: SAIA, sec 38. The same applies in Namibia (Insolvency Act 61 of 1936, sec 38) and Botswana (Insolvency Act 1929, sec 38).

62 See SAIA, secs 96-103, Namibia Insolvency Act, secs 96-103 and Botswana Insolvency Act, secs $82-88$.

63 Convention 173 of 1992.

64 Labour Relations Act 66 of 1995, sec 197A(2)(c). 
under the Labour Relations Act. ${ }^{65}$ This implies that an employer cannot dismiss an employee for reasons related to the transfer except after agreement with employees' representatives upon disclosure of all relevant information. ${ }^{66}$ In Namibia, as in Botswana, there is no express duty on the new employer to take over the contracts of existing employees and no prohibition on dismissal for reasons related to such transfers. ${ }^{67}$ In consequence, there would be unfair competition and the risk of a destructive race to the bottom or so-called "social dumping". ${ }^{68}$ Hugh Mosley explains how the phenomenon of social dumping operates:

\begin{abstract}
"Social dumping as a type of unfair competition based in sub-standards [sic] employment practices could take place in at least three inter-related ways: (1) through the displacement of high-cost producers by low-cost producers from countries in which wages, social benefits and the direct and indirect costs entailed by protective labour legislations are markedly lower; (2) firms in high labour cost countries would be increasingly free to relocate their operations, thereby strengthening their bargaining power vis-à-vis their current workforce ... to exert downward pressure on wages and working conditions; (3) individual states might be tempted to pursue a low-wage and perhaps even anti-union labour market strategy as part of their effort to catch up economically."69
\end{abstract}

Social dumping is detrimental to infant industries in the sense that it leads to unhealthy competition and even the closure of the home industries. While businesses will be attracted to areas with low labour standards, labour will be attracted to areas with high standards. This inequality must be addressed for the economic growth of the SADC countries. From this background, it appears essential that SADC has a UILA. After all, one of SADC's objectives is "to harmonize [the] political and socio-economic policies and plans of [its] member states". ${ }^{70}$ Luckily, it has the benefits experienced by OHADA to learn from. This is because OHADA is the only regional entity that has successfully enacted a uniform insolvency act which is directly binding and applicable in its contracting states.

65 Id, sec 197(6). See S Van Eck and A Boraine "A plea for the development of coherent labour and insolvency principles on a regional basis in the SADC countries" in Omar (ed) International Insolvency Law, above at note 23, 267 at 273.

66 Id, secs 197(2), 187(1)(g) and 197(6); see Van Eck and Boraine, ibid.

67 Van Eck and Boraine, id at 282 and 289.

68 T Fey "Labour standards in southern Africa in the context of globalization: The need for a common approach" (1999) 20 Industrial Law Journal 1454. Social dumping has been defined as a situation where "goods produced by means of cheap labour ... are exported to countries with higher labour standards"; see J Calitz "Harmonisation of labour law in southern Africa" 2008 De Jure 223 at 225.

69 OmarH Mosley "The social dimension of European integration" (1990) 129 International Law Review 147 at 147.

70 SADC Treaty, art 5(2)(a). 


\section{ORGANISATION FOR THE HARMONISATION OF BUSINESS LAW IN AFRICA}

This section examines OHADA and its OIA with the aim of determining the lessons SADC can learn.

\section{OHADA}

The beginnings of OHADA can be traced to the signing of the Port Louis Treaty on the Harmonization of Business Law in Africa, which entered into force in $1995 .{ }^{71}$ To date, this treaty has been ratified by 17 western and central African states: Benin, Burkina Faso, Cameroon, Central African Republic, Chad, Comoros, Congo, Democratic Republic of Congo, Equatorial Guinea, Gabon, Guinea, Guinea Bissau, Ivory Coast, Mali, Niger, Senegal and Togo. Ratification is in accordance with the constitutional procedures of the member states. ${ }^{72}$ The constitutions of most of the member states, requires the intervention of the national parliament for its authorisation. ${ }^{73}$ The immediate effects of ratification are to modify the internal laws of the signatory states and engage those states financially. ${ }^{74}$ In other words, following ratification member states are obliged to apply the uniform acts and contribute financially towards the functioning of OHADA's institutions.

Anglophone Cameroon (which operates both civil and common law systems and has both French and English as official languages) ${ }^{75}$ is distinct from the other member states because it inherited a common law system of law from the British. ${ }^{76}$ The other member states inherited French civil law from their colonial past and OHADA's official language was French. ${ }^{77}$ However, this is changing, ${ }^{78}$ as OHADA embraces other African countries. ${ }^{79}$ In a bid to involve all African states, without concern for language or history, article 42 of the

71 See above at note 6 .

72 OHADA Treaty, art 52.

73 For example, Law 95-006 of 4 April 1995 authorized the president of the Republic of Cameroon to ratify the treaty.

74 D Abarchi "La supranationalité de L'Organisation Pour L'Harmonisation en Afrique du Droit des Affaires (OHADA)" ["The supranationality of OHADA" (2000) Revue Burkinabé du Droit 10.

75 Anglophone Cameroon refers to the country's north and south-west English speaking regions.

76 MS Tumnde "Harmonisation of business law in Cameroon: Issues, challenges and prospects" (2010) 25 Tulane European and Civil Law Forum 119.

77 OHADA Treaty, art 42 provides: "Le français est la langue de travail" ["French is the working language of OHADA"]. Based on this dominance, all printing is done in French: OHADA Treaty, art 63. N Enonchong "The harmonisation of business law in Africa: Is article 42 of the OHADA Treaty a problem?" 2007 Journal of African Law 95.

78 JF Bourque "Four years on: One business law for 16 African countries", available at: <http://www.tradeforum.org/OHADA-Four-Years-On-One-Business-Law-for-16-AfricanCountries/> (last accessed 10 May 2013). 
OHADA Treaty was amended. ${ }^{80}$ The new article 42 provides for four official languages: French, English, Spanish and Portuguese. The author commends OHADA for its effort and postulates that the new article 42 will have a farreaching effect on the membership of OHADA. It will encourage other African states to join the organization.

The new article 42 not only portrays OHADA's effort in integrating English, Spanish and Portuguese-speaking African states into the system, but is also a laudable step towards fulfilling article 53 of the OHADA Treaty, which gives every member and non-member of the African Union the opportunity to join OHADA. It is noteworthy that the new article 42 emphasizes the supremacy of the French language in which the uniform acts are first published before being translated into the different languages. In the event of a conflict between the different translations, the French version prevails. ${ }^{81}$ This situation raises the issue of the authenticity of the translated versions of the uniform acts.

OHADA is an organization that strives for the harmonization of business law in Africa. ${ }^{82}$ Underlying this is the aim to attract foreign investment in order to foster regional economic integration and development of the member states. ${ }^{83}$ To this effect, nine uniform acts have been adopted by the Council of Ministers ${ }^{84}$ and five institutions created to oversee the implementation of OHADA's objectives. ${ }^{85}$ Considering the benefits to be derived from a unified business law, many African leaders have agreed to the extension of this priceless tool of economic integration to their respective countries. Nigeria, Ghana, Liberia and Angola have expressed interest in joining OHADA. ${ }^{86}$ This is a sign of confidence in the OHADA initiative. The initiative has also attracted the attention of the international community which, through the World Bank, European Union (EU) and United Nations Development Programme, has significantly contributed to and participated in its projects. ${ }^{87}$

80 Above at note 6 .

81 Revised OHADA Treaty, art 42.

82 OHADA Treaty, art 3.

83 Id, art 1.

84 Id, art 2. The tenth universal act will be on contract law; see M Fontaine "OHADA uniform act on contract law: Explanatory notes to the preliminary draft", available at: <http://www.unidroit.org/english/legalcooperation/ohada\%20explanatory\%20note-e. pdf> (last accessed 1 May 2013).

85 The Conference of Heads of State and Government, the Council of Ministers, the Permanent Secretariat, the Advanced Regional School of Magistracy and the Joint Court of Justice and Arbitration: OHADA Treaty, arts 27-41.

86 CM Dickerson "Community laws in international business transactions" in CM Dickerson (ed) Unified Business Laws in Africa: Common Law Perspectives on OHADA (2009, Kogan Pages) 1 at 1 .

87 AJ Awusu-Ansah "The OHADA Treaty in the context of international insolvency law developments", available at: <http://www.iiiglobal.org/component/jdownloads/finish/398/ 1555.html> (last accessed 10 May 2013). 


\section{Overview of OHADA Insolvency Act}

Although Anglophone Cameroon adopted a common law system, ${ }^{88}$ the provisions on insolvency in its respective jurisdictions are in pari materia [have the same subject matter] as the provisions in the other OHADA states. Hence, the legal basis for the settlement of insolvency disputes in the contracting states is the OIA and it is largely considered as it stands today. The act is composed of 280 articles divided into eight titles of unequal dimension. In contrast with other models, the OIA is not a comprehensive piece of legislation, in that it does not provide for personal and corporate insolvencies. It is still uncertain whether unitary legislation will be adopted in the near future to provide for all types of debtors. Nonetheless, the OIA has helped to harmonize conflict of laws regarding the applicable law and jurisdiction to open insolvency proceedings in the OHADA region. Under the OIA, the registered office or principal place of business and possession of assets are the criteria for starting insolvency proceedings. The act has also made it easier for parties to determine the place of jurisdiction and applicable law over insolvency disputes, which in turn helps to minimize fraud. In the words of article 25 of the OIA, insolvency refers to the inability of a debtor to settle his current liabilities with his available assets. ${ }^{89}$ To this end, the OIA offers contracting states three types of collective procedure. ${ }^{90}$

\section{Collective insolvency procedures}

The OIA reflects in its key points French national insolvency law as it stood in the mid 1990s. ${ }^{91}$ It provides for three different types of collective procedure: preventive settlement procedure (PSP); administration; and liquidation procedures otherwise called insolvency procedures. ${ }^{92}$ These procedures apply to any natural or corporate body with the status of a trader, any non-trading corporate body and any public or private corporation..$^{93}$ In other words, they apply to persons with the status of a trader ${ }^{94}$ excluding partners of partnerships, individuals, utility companies and insurance companies. ${ }^{95}$ The

88 MS Tumnde "OHADA as experienced in Cameroon: Addressing areas of particular concern to common law jurists" in Dickerson (ed) Unified Business Laws in Africa, above at note 86,70 .

89 OIA, art 25. OHADA adopts the balance sheet approach to insolvency.

90 B Wessels "Insolvency in the Middle East and Africa" (2010) 4 Quarterly Journal of INSOL International 14.

91 B Wessels "Insolvency Law" in JM Smits Elgar Encyclopaedia of Comparative Law (2006, Edward Elgar Publishing) 294.

92 OIA, art 2.

93 Ibid.

94 Art 2 of the General Commercial Law 1998 define traders as "persons whose regular occupation is to carry out commercial transactions", while art 3 defines commercial transactions as including "the purchase of movable or immovable property for resale, banking, stock and currency exchange, brokerage and transit transactions and the industrial exploitation of mines, quarries and any natural resource deposit..."

95 Insurance companies are regulated by the Inter-African Conference on Insurance (CIMA) 
collective nature of the proceedings implies a stay of individual proceedings by creditors against the property of the debtor. ${ }^{96}$ This is to ensure an orderly and equitable distribution of the debtor's assets.

The principle of equality between creditors is the preoccupation of insolvency practitioners in the treatment of international collective proceedings. This principle is manifested through a number of rules. The first relates to the liberty of creditors to prove their claims in any of the proceedings, whether principal or secondary. ${ }^{97}$ This relieves poor creditors from having to prove their claims in foreign jurisdictions. The second rule relates to the principle of restitution, under which a creditor who has received payment in one proceeding is required to return to the administrator or liquidator what he obtains. ${ }^{98}$ Accordingly, a creditor who receives in one proceeding may not participate in other proceedings open in other states relating to the same debtor unless creditors of the same rank have received an equivalent payment. ${ }^{99}$ This is to prevent preferential treatment of creditors. The third rule relates to the transfer of surplus from one proceeding to another. ${ }^{100}$ This happens in the case of multiple proceedings, that is where proceedings are open in a number of countries in relation to the same debtor. ${ }^{101}$

In principle, employees enjoy priority rights over other creditors for any outstanding wages and salaries due under their contracts of employment. ${ }^{102}$ Given that there is no redundancy or wage guarantee fund for the payment of employees, the amount is paid from the proceeds of the insolvent estate and is determined by the national employment law of the member states. Below the employees are secured creditors, followed by unsecured creditors. ${ }^{103}$ It must however be acknowledged that the granting of these procedures will depend on the financial situation of the debtor as envisaged in the expert's report. ${ }^{104}$ The fact is the debtor must be on the verge of insolvency or under threat of insolvency before he can apply for a PSP. This is evidenced by the debtor's financial statement and the expert's report. Once it is ascertained that the debtor is under threat of insolvency, a PSP will be granted. A telling example is that of the Batoula (Pty Ltd) Company of

contd

Code of 10 July 1992, as amended by Regulation 0002/CIMA/PCMA/CE/SG/2007 of 15 October 2007.

96 OIA, arts 72 and 75.

97 Id, art 253.

98 Id, art 250(1).

$99 \mathrm{Id}$, art 255.

$100 \mathrm{Id}$, art 256.

101 DN Leno "National report for Cameroon" in D Faber, N Vermunt, J Kilborn and T Richter (eds) Commencement of Insolvency Proceedings (2012, Oxford University Press) 116.

102 OIA, arts 95 and 96.

103 Id, arts 166-67.

104 An expert is not an insolvency practitioner but a judge appointed by the president of the competent court to investigate the economic and financial situation of a debtor before any of the collective procedures are granted. 
Cameroon; ${ }^{105}$ at the time of the PSP application, it had debts of 1,068,095,834 CFA francs (approximately USD 2,200). Upon receipt of the application ${ }^{106}$ and investigation by the appointed expert (Yimgnia Crispin), the company was subjected to a PSP. ${ }^{107}$ The granting of a PSP suspends all pending lawsuits, except those relating to "employees due wages" or the acknowledgement of rights or disputed debts. ${ }^{108}$ It also prohibits the debtor from making any payment or redeeming any securities except with the authorization of the president of the competent court. ${ }^{109}$

On the other hand, the granting of insolvency orders is in respect of insolvent debtors. ${ }^{110}$ That is, against debtors who are unable to meet their liabilities with their available assets (balance sheet insolvency). ${ }^{111}$ The difference between the insolvency orders lies in the purpose for which they are designed. While liquidation is designed for the realization of the assets of an insolvent debtor for the satisfaction of his creditors' claims, an administration procedure [redressement judiciare] is designed to rescue financially troubled debtors who are capable of survival. According to Awusu-Ansah, ${ }^{112}$ administration "has the effect of placing the debtor under 'compulsory assistance' for the administration and disposal of his property". ${ }^{113}$ As in France, it takes effect from the date of its pronouncement. ${ }^{114}$ Any objection or appeal to the procedure must be made within 15 days from the date of publication of the judgment. ${ }^{115}$ In Sonsbhy $v$ Tangui Petroleum Company, ${ }^{116}$ the Court of Appeal of Ouagadougou rejected an appeal for non-compliance with the deadline.

\section{International collective procedures}

The international collective provisions are part and parcel of the OIA, applicable only in the event of cross-border disputes. The essence therefore is to facilitate cooperation between the member states and the tasks of the liquidator or administrator. It is worth mentioning that these provisions are inspired by several international instruments, such as the European Convention on Insolvency Proceedings, ${ }^{117}$ the European Convention on

105 This is a public limited company created in 1974 with its registered office in Cameroon. It manufactures whipped cream.

106 It is unfortunate that the OIA does not state the persons responsible for initiating a PSP.

107 See the High Court of Wouri, Douala order 845/PTGI/W/DLA of 17 December 2008 and civil judgment of 27 May 2009.

108 OIA, arts 8, 12 and 22.

109 Ibid.

$110 \mathrm{Id}$, art 25.

111 Ibid.

112 See Awusu-Ansah "The OHADA Treaty", above at note 87.

113 OIA, arts 35-36.

114 Id, art 52 and French Decree 21 of 1988, art 2.

115 OIA, arts 216-25.

116 Judgment 39/2002 of 5 April 2002.

117 This did not enter into force due to one member's failure to ratify it. However, it has 
Certain International Aspects of Bankruptcy ${ }^{118}$ and the UNCITRAL Model law on Cross Border Insolvency (Model Law). ${ }^{119}$ Unlike the OIA, the Model Law is not a convention but a law designed for adoption by any country in dealing with cross-border insolvency issues. ${ }^{120}$ Furthermore, it is flexible in that it gives enacting states the option to add or omit some provisions of the law in order to fit in their national jurisdictions. ${ }^{121}$ Like the OIA, it provides for two types of insolvency proceedings: foreign main and foreign non-main proceedings. ${ }^{122}$ The OIA provisions also reflect several issues of the EU Regulation on Insolvency Law (EU Regulation). ${ }^{123}$ To mention a few, both the OIA and the EU Regulation provide for main and secondary proceedings, and provide the registered office or principal place of business criteria for opening main proceedings. ${ }^{124}$ In addition, both laws entrust the liquidator with the responsibility of taking measures necessary to ensure the publication of the liquidator's order on the request of a member state. ${ }^{125}$

A cross-border dispute sets in when a debtor has assets across a number of jurisdictions; when this happens, there will still only be one set of proceedings, referred to as "primary collective proceedings". If primary collective proceedings are opened in one country, the judgment instituting the proceedings will be res judicata [a matter that has been finally adjudicated] in the territory of the other member states. ${ }^{126}$ Creditors in other member states are entitled to institute their claims in that country, ${ }^{127}$ and the insolvency practitioner (administrator or liquidator) may exercise his powers in any of the member states as long as no other collective proceedings have been initiated in that state. ${ }^{128}$ This is to ensure that local and international creditors are protected. However, the commencement of primary collective proceedings does not bar

contd

been superseded by the current council regulation (EC) 1346/2000 of 29 May 2000 on insolvency proceedings.

118 Council of Europe, 5 June 1990.

11930 May 1997. Available at: <http://www.uncitral.org/pdf/english/texts/insolven/ insolvency-e.pdf> (last accessed 23 April 2013).

120 EN Sayi Harmonisation of Insolvency Law, above at note 11 at 26.

121 Ibid.

122 Model Law, art 2 (c).

123 EU Regulation 2000, arts 16, 17 and 25.

124 Id, arts 3(1) and 27 and OIA, art 251.

125 OIA, arts 21 and 22.

126 OIA, art 247; P Tiger "Les procédures collectives après cessation des paiements en droit harmonise de l'OHADA" "The OHADA Uniform Act on Collective Proceedings for the Wiping of Debts"] 2004 Petites Affiches 35.

127 Regarding distribution, any surplus realized from one proceeding must be transferred or handed over to administrators or liquidators in other insolvency proceedings: OIA, art 256. Thus, a creditor who has received payment in one proceeding, say the principal proceeding, is not allowed to receive payment in secondary proceedings until other creditors of the same class of preference have been paid: OIA, art 225 .

Id, art 249. 
the commencement of "secondary collective proceedings". ${ }^{129}$ For example, if a debtor has its registered office in Cameroon and branches in the Ivory Coast and Senegal, primary collective proceedings will be opened in Cameroon and secondary collective proceedings in Senegal and in the Ivory Coast respectively.

The case of Attiba Dennis and Others $v$ Multinational Air Afrique Companies and Others ${ }^{130}$ is a "landmark victory for the OHADA initiative and marks the beginning of confidence" in the OIA. ${ }^{131}$ Air Afrique, a multinational airline, was the pride of Africa with over 46,000 employees. It was owned by 11 OHADA member states, ${ }^{132}$ Air France, the French Development Agency and three private stockholders. ${ }^{133}$ The company experienced severe financial difficulties due to poor management and badly negotiated Airbus lease agreements. In an attempt to keep the company running, the 11 member states met the World Bank (WB) to devise modalities for assistance. This failed because the member states did not accept the WB's suggestions of privatization and restructuring. ${ }^{134}$ For its part, Air France suggested renaming the company New Air Afrique and bringing in new investors. ${ }^{135}$ This was found to be complicated and thus was rejected. ${ }^{136}$ In accordance with article 25 of the OIA, the company filed for bankruptcy in Abidjan where it had its centre of administration. Taking into account the fruitless rescue attempts and the degree of the company's indebtedness, the court decided on liquidation. ${ }^{137}$

\section{Lessons learned}

The first lesson relates to the realization that collective effort is necessary in an era of globalization. When states cooperate in the enactment of an insolvency law, one end result should be that the contracting states will enjoy a simple, modern and accessible insolvency law. The advantage of this is that it facilitates the movement of assets from one country to another, cooperation between insolvency practitioners and settlement of cross-border insolvency

$129 \mathrm{Id}$, art 251.

130 The Common Court of Justice and Arbitration (CCJA) 7 February 2002.

131 See Awusu-Ansah "The OHADA Treaty", above at note 87 at 7.

132 Benin, Burkina Faso, Central African Republic, Chad, Congo, Ivory Coast, Mali, Mauritania, Niger, Senegal and Togo.

133 The 11 member states were the majority shareholders with $68.4 \%$ stake in the company; Air France held $12 \%$, the French Development Agency $9 \%$, with the other stockholders holding $10.6 \%$.

134 Awusu-Ansah "The OHADA Treaty", above at note 87 at 6.

135 See African Development Bank "Multinational company Air-Afrique reinforcement project: Project completion report”, available at: <http:// www.afdb.org/fileadmin/ uploads/afdb/ Documents/Project-and-Operations/ADB-BD-IF-99-310-EN-MULTINATION AL-PCR-MULTINATIONAL-COMPANY-AIR-AFRIQUE-REINFORCEMENT-PROJECT.PDF> (last accessed 1 May 2013).

136 BBC "Air Afrique wound-up", available at:<http://www.airliners.net/aviation-forums/ general_aviation/read. main/545737/> (last accessed 1 May 2013).

137 Judgment 04/2004 of 8 January 2004; OIA, art 32. 
disputes. The second lesson relates to the provisions of the OIA being selfexecuting so as to enjoy precedence over nationally enacted insolvency law. ${ }^{138}$ This implies that, upon ratification of the OHADA Treaty by a state, the state becomes automatically bound by the provisions of the treaty, OIA and other uniform acts. ${ }^{139}$ This eliminates every possibility of escape by contracting states from their international obligations and thus creates a sense of unity of purpose among the contracting states. Because the provisions of the treaty and the uniform acts are automatically binding upon ratification, the treaty makes no provision for sanctions.

Thirdly, the OIA envisages the "creditor wealth maximization vision" which sees insolvency as a process of collecting debts for creditors and a response to the common pool problem (wiping out debts). Once any of the collective insolvency proceedings set in, there is an automatic stay of individual proceedings against the debtor. ${ }^{140}$ This of course protects vulnerable creditors. The creditors concerned are those whose claims arose before the judgment which put the debtor into collective proceedings. Added to this is the fact that the OIA does not provide for a discharge. Under the OIA, a debtor is discharged from all his liabilities and disqualifications and is restored to his civil and commercial status only after payment of his debts in full. ${ }^{141}$ Moreover, the OIA establishes a corporate rescue regime with a dual procedure: composition and administration. According to this procedure, when a company is insolvent and prospects of recovery are good, the company is required to file an application for administration alongside an offer of composition. ${ }^{142}$

It is equally important to note that the OIA applies in and outside formal insolvency proceedings and that insolvency representatives are known are "administrators" in the case of business rescue and "liquidators" in the case of a company which is wound up. The OIA does not state the grounds for the appointment of insolvency representatives. The insolvency representatives are not practitioners, but judges appointed in their personal capacity as judges to handle insolvency proceedings. They receive salaries for their services as servants of the state in the administration of insolvent estates. ${ }^{143}$ The judges do not attend any professional school ${ }^{144}$ to acquire knowledge of the administration of insolvent estates, as is the case in South Africa and the rest of the developed world. Based on the author's knowledge of insolvency law and practice, an insolvency practitioner should be able to draft a liquidation, distribution and contribution account; however judges within the OHADA region

\footnotetext{
138 OHADA Treaty, art 10.

139 Ibid.

140 OIA, arts 72 and 75.

141 I Fletcher Cross-Border Insolvency: Comparative Dimension (1999, United Kingdom Comparative Law Series) at xxi.

142 OIA, arts 7 and 119.

143 Leno "National report for Cameroon", above at note 101 at 19.

144 In Cameroon, judges are appointed after two years' training at the School of Administration and Magistracy.
} 
possess little knowledge of these issues. Therefore, it remains to be seen how insolvent estates will be administered within the OHADA region.

In addition, insolvency issues are a court driven process. The OIA gives the courts too many arbitrary powers to serve what they consider to be collective interests and to ensure the effectiveness of collective proceedings. It is essential to note that there is no specialized commercial or insolvency court for the settlement of both national and international insolvency disputes within OHADA. Rather, there are general courts which vary from one member state to another. This diversity is an obstacle to the drafter's drive for uniformity. In Cameroon, for example, whether a court is considered competent in commercial matters is determined by the size of the disputed claim. When the amount of the disputed claim is less than 500,000 CFA francs, ${ }^{145}$ the matter is set down for hearing before the court of first instance but, if it exceeds that amount, it is set down for hearing before the High Court of Cameroon. In Mali, an application to commence insolvency proceedings is filed before the Commercial Court; in the Ivory Coast it is the Civil and Commercial division of the competent court; in Senegal it is the Regional Tribunal; and in Burkina Faso the High Court.

However, there is a supranational court for the settlement of commercial disputes: the Cour Commune de Justice et Arbitrage ${ }^{146}$ [the Common Court of Justice and Arbitration] (CCJA). This special court is in charge of disputes relating to the application and interpretation of the OHADA Treaty and the uniform acts. ${ }^{147}$ As the Supreme Court, it hears appeals against decisions of the national appeal and lower courts of the member states. ${ }^{148}$ The national courts retain jurisdiction at first instance and the CCJA has jurisdiction on appeal. ${ }^{149}$ Decisions of the CCJA are res judicata and enforceable in the member states. ${ }^{150}$ In the event of a conflict of jurisdiction between a national supreme court and the CCJA, when in fact the matter falls within the jurisdiction of the CCJA, the national supreme court must decline jurisdiction over the matter and refer the case to the CCJA. ${ }^{151}$ If the CCJA does not have jurisdiction, then the matter will be referred to the competent national court which will hear the case. ${ }^{152}$ In Souleymane Cherif $v$ Société Chronopost International Côte d'Ivoire, ${ }^{153}$ the CCJA declared itself incompetent to rule on a matter which involved the suspension of an execution granted on the basis of article 214

145 This is equivalent to approximately USD 1,000.

146 The CCJA is located in Abidjan in the Ivory Coast; see: <http://www.aict-ctia.org/ courts_ subreg/ohada/ohada_home.html> (last accessed 30 April 2013).

147 J Meyer "La sécurité juridique et judiciaire dans l'espace OHADA" ["Legal and judicial security within the OHADA space”] 2005 Revue Penant 151.

148 OHADA Treaty, art 13.

149 Id, art 14.

$150 \mathrm{Id}$, art 20.

151 Id, art 15.

152 Id, art 16.

153 Judgment 001/2005 of 27 January 2005. 
of the Civil Procedure, Administrative and Commercial Code of the Ivory Coast on the grounds that it fell outside its domain of competence as stipulated in articles 14(3) and (4) of the OHADA Treaty.

Ultimately, OHADA's success in adopting a uniform insolvency act, presupposes other things, such as the stage of integration in the region and, most importantly, the willingness of the contracting states to harmonize their business law. In a nutshell, commitment by states is a prerequisite for a successful integration process without which the whole project will remain "pie in the sky". As Ruppel rightly pointed out, "without political will and good faith on the part of ... states to meet and comply with their obligations as spelt out in ratified treaties and conventions, economic regional integration is likely to remain a concept on paper". ${ }^{154}$

\section{RECOMMENDATIONS}

The debate on the enactment of a uniform insolvency law approach revolves around the method to establish such an approach and the form of the legislation. Smits distinguishes between the centralist and the non-centralist method of creating uniformity. According to him, the traditional centralist method creates uniformity by way of a binding treaty: a method he argues had not been very successful in the field of private law. ${ }^{155}$ The non-centralist method establishes uniformity by way of principles which serve as a model. ${ }^{156}$ From this, the author argues that, in order to warrant a higher degree of legal certainty, transparency and predictability, the provisions of the unified legislation should be contained within a legal framework (treaty) that actually imposes a duty of adherence on member states. Such a framework would facilitate member states' understanding of their own and shared interests, information gathering and exchange of ideas. ${ }^{157}$ The adoption of a treaty would serve as an indication that states are willing to integrate their economies and comply with the treaty provisions.

The fear of non-compliance is one of the major challenges which, according to many, stifle potentially beneficial cooperation between states. Mike Campbell $v$ Republic of Zimbabwe is a telling example. ${ }^{158}$ In this case, the government of

154 O Ruppel "The case of Mike Campbell and the SADC Tribunal under review" (paper presented at the second international conference on regional integration and SADC law, Maputo, Mozambique, 9-11 November 2010) at 12.

155 J Smits The Contribution of Mixed Legal Systems to European Private Law (2001, Intersentia Uitgevers Antwerpen) at 2.

156 Ibid.

157 See J Brunee and ST Toope "Environmental security and fresh water resources: Ecosystem regime building" (1997) 91 American Journal of International Law 26, in which the authors suggest and urge the use of a framework convention.

158 SADC T 2 2007. See D Memory and R Midgley "Land reform in Zimbabwe: Context, process, legal and constitutional issues and implications for the SADC region" 2008 Monitoring Regional Integration in Southern Africa Yearbook 1. 
Zimbabwe expropriated a number of white owned agricultural lands. This followed an amendment to the country's constitution. Section $16 \mathrm{~B}(2)$ of the Zimbabwe Constitution ${ }^{159}$ reads in relevant part as follows: "(a) all agricultural land ... is acquired by and vested in the state with full title therein ...; and (b) no compensation shall be payable for land referred to in paragraph (a) except for any improvements effected in such land before it was acquired". ${ }^{160}$ Mike Campbell (Pvt) Ltd and William Michael Campbell, whose lands were expropriated, filed an application with the SADC Tribunal challenging the taking by the state of their lands. The applicants contended that the land acquisition process was racist and contravened article 6 of the SADC Treaty which outlaws arbitrary and racially motivated government action. ${ }^{161}$ The tribunal concluded that the Republic of Zimbabwe was in breach of its obligations under 4(c) and 6(2) of the SADC Treaty. This ruling is considered to be a landmark decision which will without doubt influence the legal landscape in the region.

According to Voeten, ${ }^{162}$ non-compliance is not a wilful act but arises from a number of issues, including the complexity of the implementing agreement, the ambiguity and indeterminacy of treaty language, limitations on the capacity of parties to carry out their undertakings, and the temporal dimension of social, economic and political changes contemplated by regulatory treaties. ${ }^{163}$ In trying to address the issue of non-compliance, the provisions of the treaty and those of the unified legislation should be directly applicable in the member states. This would signify the loyalty and fidelity on the part of the member states in the observance, in good faith, of the treaty provisions, "being an element of the principle of pacta sunt servanda [agreements must be kept], according to which [member states] have the obligation to observe"164 and comply with their treaty

159 As amended by Amendment Act No 17 of 2005.

160 See DP Zongwa "The contribution of Campbell $v$ Zimbabwe to foreign investment law on expropriations" (2010) 22 Namibia Law Journal 29.

161 SADC Treaty, art 6(2) provides: "SADC and Member States shall not discriminate against any person on grounds of gender, religion, political views, race, ethnic origin, culture, ill health, disability, or such other ground as may be determined by the Summit", while art 4 provides that SADC and its member states shall act in accordance with the following principles: “(a) sovereign equality of all Member States; (b) solidarity, peace and security; (c) human rights, democracy and the rule of law; (d) equity, balance and mutual benefit; and (e) peaceful settlement of disputes."

162 E Voeten "Regional judicial institutions and economic cooperation: Lessons for Asia" (2010, Asian Development Bank working paper series on regional economic integration) at 18 .

163 AM Kacowicz "Compliance and non-compliance with international norms in territorial disputes: The Latin American record of arbitration” in E Benvenidti and M Hirsch (eds) The Impact of International Law on International Co-operation: Theoretical Perspectives (2004, Cambridge University Press) 194 at 198.

164 RA Wessel "Reconsidering the relationship between international and EU law: Towards a content-based approach?”, available at: <http://www.utwente.nl/mb/pa/research/ wessel/wessel74.pdf> (last accessed 29 April 2013) at 8. 
obligations. ${ }^{165}$ In addition, the SADC Council of Ministers should be empowered as a "guardian of treaties", responsible for making sure that the provisions of the treaty and unified legislation are properly applied in all member states. ${ }^{166}$ Like the European Commission, the council should be able to bring before the SADC Tribunal enforcement proceedings against a non-complying state. ${ }^{167}$ Preceding this, the concerned state should be given an opportunity to submit its observations. ${ }^{168}$

As regards the form of the insolvency legislation, the author suggests unified legislation, applying equally to both individual and corporate insolvency, as far as possible. ${ }^{169}$ Unified legislation saves costs and avoids conflict and duplication, which according to Boraine and Van der Linde "create difficulties with interpretation". ${ }^{170}$ In other words, many aspects of insolvency which affect individuals and corporate insolvency should be the same. ${ }^{171}$ The Cork Committee of England made a good point in support of this contention when it said:

"We feel that there is a sound basis for this unification approach, for the material form of the debtor may be dictated as much by history, tax advantage or legal protection as by any other consideration. For example, a family business may be conducted as a partnership or through the medium of a limited company. Such differences should not obscure the essential unity of the relationship between the debtor, the creditors of the debtor and other interests." ${ }^{172}$

Policy choices regarding the debtors, their creditors and other interests should be balanced. To guarantee continuity in business, debtors should be given the opportunity to make a fresh start (discharge) and opportunity to restructure potentially viable businesses. In addition, the law should guarantee certainty in capital markets so that lenders can make prudent lending choices, before, during and after insolvency. ${ }^{173}$ As for employees, ${ }^{174}$ they should be granted

165 See A Chayes and AH Chayes The Sovereignty: Compliance with International Regulatory Agreements (1998, Harvard University) at 3.

166 M Cuthbert European Union Law (6th ed, 2009, Thomson Reuters Ltd) at 12.

167 EC treaty, art 226, which provides: "If the commission considers that a member state has failed to fulfil an obligation under the treaty, it shall deliver a reasoned opinion on the matter after giving the state concerned the opportunity to submit its observations. If the state concerned does not comply with the opinion within the period laid down by the commission, the latter may bring the matter before the court of justice."

168 Ibid.

169 See the United States Bankruptcy Act of 1978.

170 See A Boraine "The Draft Insolvency Bill: An exploration” (part 1) 1998 Journal of South African Law 621.

171 A Keay To Unify or Not to Unify Insolvency Legislation: International Experience and the Latest South African Proposals (1999, De Jure) at 71.

172 Id at 79.

173 Sarra "Widening the insolvency lens", above at note 59 at 296.

174 "Employee" here means anyone who is subject to the control of an employer. 
absolute priority for all outstanding claims over other creditors. ${ }^{175}$ Added to this, a mixture of both a guarantee fund mechanism and wage protection or "fund for compensation" should be developed for cases of closure or lay-off. This is with the view of providing employees with timely financial relief. ${ }^{176}$ As to its sources and management, the fund should be managed by a government representative and receive contributions from social security schemes, employees' salaries and wages, and other state sources. ${ }^{177}$

To ensure that the law is well received and not resisted, it should be given a community-based perspective. Accordingly, a working committee should be established, composed of the different stakeholders. The committee should be entrusted with the task of investigating the feasibility of the project, carrying out a comparative study on the subject and preparing a draft document, which could be called "comparative insolvency law of SADC". Interestingly enough, a regional centre for studies on integration and SADC law was established at the Eduardo Mondlane University, Maputo, Mozambique to this effect. The draft document should be sent to a committee of experts from the region: senior civil servants, magistrates, lawyers, notaries, academics and representatives of the business world. The main task of the committee should be to draw up the text following a comprehensive report by the regional centre, taking into account the legal peculiarities of each legal system. Not only will such a legal norm gain importance in the future, but it will also promote flexibility and bring together common law and civil principles, and hence be widely acknowledged.

To promote institutional collaboration among the SADC institutions, once the text has been drafted, it should be sent to the member states and the SADC national committees for comment, and to the tribunal and the Integrated Committee of Ministers for their advisory opinions and to verify whether the draft version accords with the treaty and the general spirit of SADC. One month should be allowed for comments and opinions. This process is important for the member states and the tribunal. While it gives the member states an opportunity to acquaint themselves with the new law, it gives the SADC tribunal the opportunity to understand the philosophy behind the OIA, which will help it in rendering its judgments. At the close of the consultative period, the comments and the advisory opinions would be forwarded to the committee of experts. The committee would finalize the draft version, taking into account the observations and comments of the member states and opinions of the tribunal and Integrated Committee of Ministers, and then forward the final copy to the SADC Summit for adoption.

To have successful legislation implemented, it is most useful for SADC states to recognize the importance of the project and to accept all that contributes to this goal, through giving their full support and ceding or transferring a

175 See Tumnde "Harmonisation of business law in Cameroon", above at note 76.

176 Sarra "Widening the insolvency lens", above note 59 at 311.

177 Id at 296. 
certain amount of their sovereignty. Issues of sovereignty are encountered when it comes to integration, and successful economic regional integration requires such concerns to be dealt with sensitively and effectively. ${ }^{178}$ Given its relevance and place in such a project, SADC member states should be prepared to cede part of their sovereignty to SADC. To do so, the member states' constitutions must expressly provide for their governments to be able to transfer sovereign powers to SADC. ${ }^{179}$ Allan writes that "political will is a crucial ingredient in the integration process", without which there will be little progress. ${ }^{180}$ As Ruppel rightly pointed out, "without political will and good faith on the part of ... states to meet and comply with their obligations as spelt out in ratified treaties and conventions, economic regional integration is likely to remain a concept on paper". ${ }^{181}$ Therefore, there must be political will on the part of SADC leaders to adhere to the objectives of the treaty and the provisions of the unified legislation.

\section{CONCLUSION}

Clearly, the settlement of cross-border insolvency disputes presents no difficulty for OHADA contracting states. SADC states are therefore urged to enact uniform insolvency law provisions. There is no doubt that this would come at some cost, but efforts must continue until the objective is achieved. SADC leaders and their collaborators (academics, businessmen and students) have the responsibility to pursue such integration. In a nutshell, it would be both practical and good administrative practice to have one set of insolvency laws in the SADC region that would do away with uncertainty and ambiguity in cross-border commercial transactions among SADC states. It is hoped that SADC will rise to the challenge and engage with all of the above issues.

178 See O Ruppel "The question of land ownership in post-colonial African development" (Economic Community of Central African States, fourth European conference on African studies, Uppsala, 15-18 June 2011: panel 133), available at: <http://www.nai.uu. se/ecas-4/panels/121-140/panel-133/Oliver-Ruppel-full-paper.pdf> (last accessed 24 November 2011).

179 D Sarooshi International Organizations and Their Exercise of Sovereign Powers (2005, Oxford University Press) at 65.

180 D Allan Regional Integration and Food Security in Developing Countries (2003, Practicing Law Institute) at 8.

181 Ruppel "The case of Mike Campbell", above at note 154 at 12. 